\title{
1. LEG 68: INTRODUCTION, EXPLANATORY NOTES, AND CONVENTIONS ${ }^{1}$
}

The sixty-eighth cruise of Glomar Challenger was devoted to using the newly developed Hydraulic Piston Corer (HPC) to recover undisturbed, continuous sequences of unlithified sediment. We returned to the vicinities of two rotary-drilled sites ( 83 and 154). The stratigraphy of these sites indicated that uninterrupted sections of late Neogene and Quaternary sediment should exist at these locations. The ship left Curaçao, Dutch Antilles, on 13 August 1979, cored for 11 days at Site 502 , and transited from the Caribbean through the Panama Canal. Site 503, in the eastern equatorial Pacific, was cored for seven days, and we then finally transited to Salinas, Ecuador. The results of this cruise (reported in this volume) include preliminary descriptions, based primarily on shipboard observations and analyses, of the material recovered (site chapters) and additional studies performed ashore after the cruise, either by scientists who participated in the cruise or by other invited investigators. The main purpose of this volume is to present not an exhaustive study of the sediment recovered but rather a description, as detailed as possible, of the material recovered on Leg 68 accompanied by interpretations and conclusions that remain preliminary.

\section{OBJECTIVES FOR LEG 68}

The general objectives of this cruise were to use the newly developed HPC to recover two undisturbed, continuous records of the late Neogene and Quaternary, one from the western Caribbean and the other from the eastern equatorial Pacific, and to test the coring capabilities of the HPC. The HPC had been successfully used only once before (Leg 64, Site 480) (Curray and Moore, 1979; Schrader et al., 1980), and it recovered a spectacular section of laminated (or varved) diatomites from the Gulf of California. This initial success inspired strong interest among the paleoceanographic community in using the HPC to continuously core high priority sites that were thought to have continuous records, to be pelagic or at least to contain a high biogenic component, and to be optimally located for answering important paleoceanographic questions. Previous attempts to obtain detailed records at some of these locations were plagued by spot coring, poor recovery, and badly disturbed sediment.

\section{THE EVOLUTION OF LEG 68}

The Ocean Paleoenvironment Panel of IPOD, with the help of an ad hoc committee spearheaded by Dr. James D. Hays, Lamont-Doherty Geological Observatory of Columbia University, chose a series of sites in

\footnotetext{
${ }^{1}$ Prell, W. L., Gardner, J. V., et al., Init. Repts. DSDP, 68: Washington (U.S. Govt. Printing Office).
}

the world's oceans that were of highest priority to the greatest number of workers in paleoceanography, biostratigraphy, and magnetostratigraphy. Preliminary plans called for an HPC leg to include the eastern equatorial Pacific and the Caribbean in November 1979. However, mechanical failure during August 1979 (Site 501) required a transit to Curaçao for an unscheduled port call and the suspension of that leg. Quickly, the IPOD committees convened and decided to insert the "HPC leg" into the schedule. A scientific staff was hurriedly assembled and rushed to Curaçao. The objectives of the new Leg 68 (the cruise reported in this volume) were to return to the vicinity of Site 154 in the western Caribbean and to Site 83 in the eastern equatorial Pacific, to core at least three overlapping holes as deep as possible and to test the penetration of the HPC. The cores were to be offset so that core breaks in one hole would fall mid-core in an adjacent hole. We were to monitor the performance of the HPC as well as the physical properties of the recovered sediment. In addition, we were to use the long-core spinner magnetometer to record the detailed paleomagnetic history of the sections.

We knew the sediment at Site 502 in the Caribbean would be a hemipelagic facies with accumulation rates of about $3 \mathrm{~cm} / \mathrm{k}$.y. Site 154 recovered a coarse-grained volcanogenic turbidite sequence at a depth equivalent to a strong seismic reflector (Edgar, Saunders, et al., 1973). We purposely chose a section where this strong reflector was absent so that we could recover a maximum pelagic-hemipelagic section.

Our second site required us to relocate as close as possible to rotary-drilled Site 83 in the eastern equatorial Pacific. Working within a time constraint, we were to use the techniques perfected at the Caribbean site to recover a complete sequence with the HPC. Previous work at this location (Hays et al., 1972) indicated that we would find a siliceous-calcareous pelagic facies with accumulation rates of about $3 \mathrm{~cm} / \mathrm{k} . \mathrm{y}$.

The IPOD Ocean Paleoenvironment Panel hoped, as did the shipboard scientists, that the successful recovery of the late Neogene and Quaternary records from these two sections would help define the timing of the emergence of the Isthmus of Panama and initiation of Northern Hemisphere glaciation and provide data on the adjustments of oceanic currents to changing global climatic conditions. In addition, these two low-latitude sections could be used as biostratigraphic reference sections that are correlated with a continuous paleomagnetic record.

\section{DESCRIPTION OF THE HPC}

The HPC (Fig. 1) consists of a 4.4-m core barrel that slides over a stationary piston assembly. The corer is "cocked" by shear pins that hold the barrel in a re- 


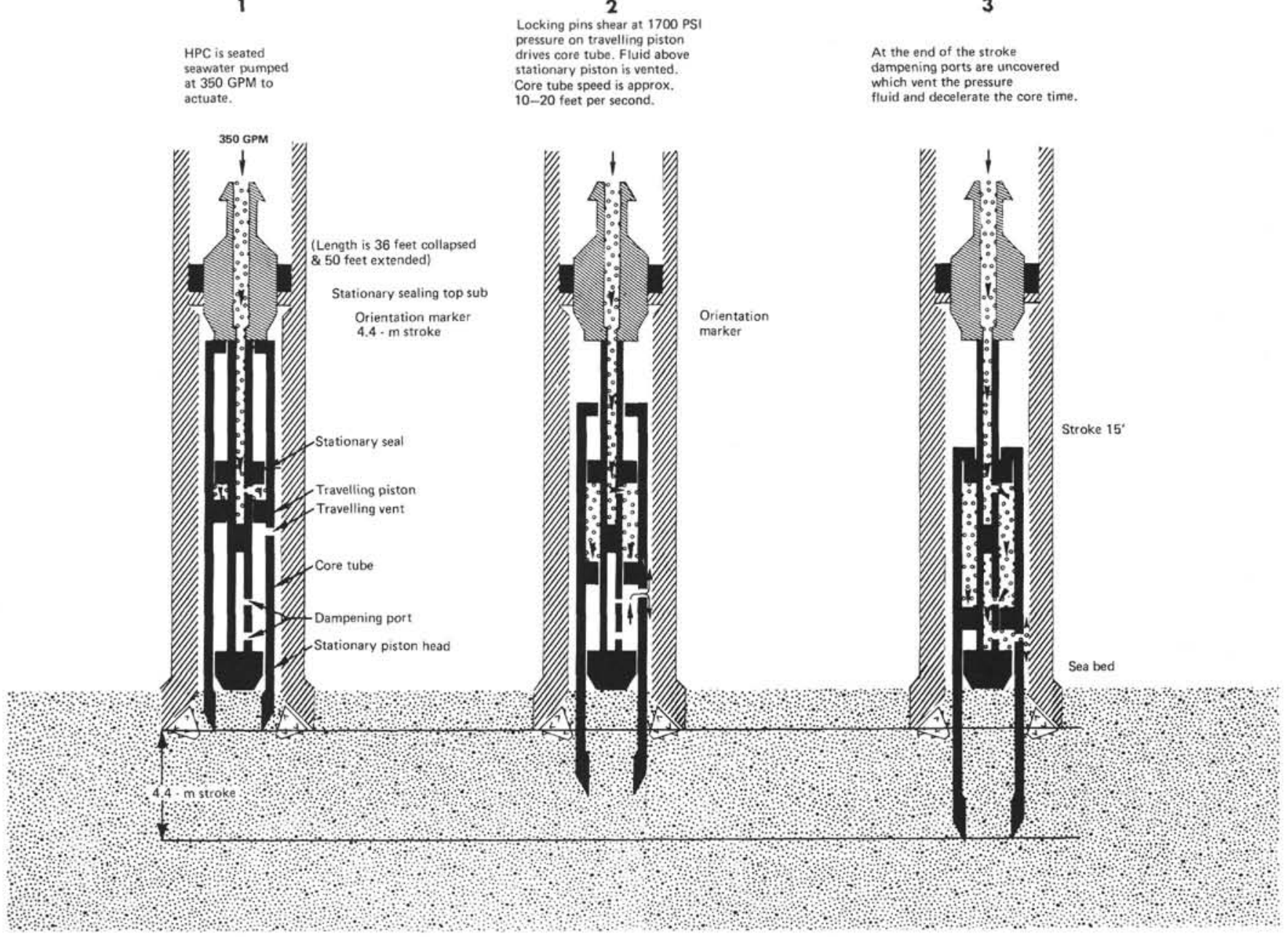

Figure 1. Schematic diagram and operational sequence of the HPC.

tracted position. The HPC is lowered down the drill string and set into the bottom hole assembly; seawater is then pumped down the drill string until the shear pins fail. The HPC strokes out ahead of the drill bit, using the hydraulic pressure as the driving force. Once the HPC is fully extended, the hydraulic pressure is released through ports (Fig. 1). If the HPC does not fully extend, the pressure is not released until the entire drill string is raised to the point where the HPC is fully extended. The complete firing sequence takes less than a minute. The major time consumption in using the HPC is transit between the seafloor and the ship. The great advantage of the HPC is that it recovers undisturbed sediment that is suitable for detailed paleomagnetic, biotic, and sedimentological analyses. The undisturbed nature of these cores is illustrated by the comparison of rotary-drilled and HPC cores from the same location and stratigraphic interval (see Frontispiece, this volume).

\section{EXPLANATORY NOTES AND CONVENTIONS}

\section{Coring Procedures}

When the HPC fully extends $(4.4 \mathrm{~m})$ but recovery is less that 4.4 meters, the loss of sediment usually resulted from failure of the core catcher or from cracked core liners. We attempted to recore intervals of low or no recovery and found that the second core was always badly disturbed and of almost no use; therefore we discontinued the recore procedure.

We recommend using leaf-spring core catchers with plastic socks in the upper part of the section where sediment shear strengths are less than $750 \mathrm{~g} / \mathrm{cm}^{2}$. Flappertype core catchers can be used in sediment with shear strengths greater than $750 \mathrm{~g} / \mathrm{cm}^{2}$, making certain that double springs are attached to the flapper. Sediment with shear strengths greater than $1000 \mathrm{~g} / \mathrm{cm}^{2}$ should be cored using the hard formation lug-type core catchers.

Once the HPC did not fully stroke out (as indicated by the absence of a drop in water pressure), a continuous section could be recovered by measuring the amount of recovery on a core, then dropping the drill string to the nearest 0.5 meter less than the previous recovery. For instance, if Core 36 recovered 3.37 meters of sediment, we would lower the drill string 3.0 meters for the coring of Core 37 . This approach insures some overcoring of disturbed sediment but does not lose any uncored sediment.

We found that polybuterate liner breakage and/or collapse often impeded or eliminated recovery of sediment. The core liner should not be cut shorter or longer 
than the HPC barrel. We had our best success when the liner was measured accurately. We also discovered that using weaker shear pins in the HPC reduced the frequency of collapsed liners. Unfortunately, neither remedy totally eliminated the problem, and we were vexed by broken liners throughout the cruise.

\section{Core Orientation}

Because magnetostratigraphy was one of the prime objectives of our leg, we attempted to orient the cores relative to each other. We marked the orientation of the HPC relative to the bottom hole assembly (BHA) because the HPC can rotate within the drill string. The orientation of the drill string and BHA relative to the ship was recorded. Ship heading changed less than $10^{\circ}$ during the coring of any hole. The orientation of the HPC was recorded on an aluminum ring located below the top sub (see Fig. 1). The ring was aligned with a set screw that screwed it to the HPC but not to the BHA. This orientation was recorded by a raised marker when the HPC seated into the BHA. The angle of this mark relative to the drill string (i.e., ship's heading) was recorded for each core and used to determine the relative orientation between cores (see palomagnetic data appendix on microfiche in back of this volume). Unfortunately, as sub-bottom depth increased, so did the number of indentations on the orientation ring. We selected the clearest and deepest indentation. The orientation angle was used to scribe a line along each core liner so that all sections of each core were split along the same azimuth and also so that each core of the hole would be aligned to the same azimuth. The azimuth chosen for orientation was the heading of the ship.

\section{Core Handling}

The quality of HPC cores is a direct result of proper handling. Orientation of the cores for paleomagnetics requires careful examination of the orientation ring, careful measurement of the orientation angle, transcribing that angle onto the liner, and tender handling of the section. Because the purpose of HPC cores is to collect continuous high-resolution stratigraphic sections, contamination is a very serious problem. Major contamination is encountered on the deck where the core catchers are dissassembled and core catcher samples are taken. Very often the table and tools provided for this operation were not thoroughly and carefully cleaned with water and compressed air. This carelessness degraded the core catcher samples and often hindered the paleontologist's work. We found that the magnetics data were more consistent when extra care was taken not to bang or bend the core. Also, the magnetics data were improved when we kept the sections of core as vertical as possible prior to the measurement of natural remanent magnetization (NRM). Core handling began with first recording the azimuth of the mark on the orientation ring for paleomagnetic orientation. This azimuth was scribed relative to a permanent mark on the liner along the length of each core before it was cut into 1.5 -meter sections. Once scribed, the core was subdivided into 1.5 -meter-long sections. Traditional DSDP conventions were used to num- ber each section; Section 1 is the top 1.5 meters of each core. In some cases (e.g., Hole 502, Core 23), the sediment in the liner support (i.e., above the core liner) was labeled Section 1. The cores were subdivided, sealed, and labeled, then immediately turned vertical and sent to the paleomagnetics lab. After long-core spinner paleomagnetics measurements were made, each section was processed through the GRAPE (Gamma Ray Attenuation Porosity Evaluator) device for physical properties and the sections split. Once split, one half was labeled "working half" and the other, "archive half." Subsamples for either shipboard or shore-based analyses were all taken from the working half. The archive half was used for shipboard lithological description and photography. Both halves were stored in the ship's cold storage facility.

All cores now reside in cold storage at the DSDP West Coast Repository at Scripps Institution of Oceanography, La Jolla, California, and are available to interested investigators.

\section{Sub-bottom Depths}

Coring with the HPC requires extremely careful record-keeping of the sub-bottom depth of each coring attempt. We realized after the cruise that in order to correlate depth in one hole to depth in another at the same site, some allowance had to be made for recoring an interval already cored on the previous attempt and for gaps in the sediment due to core handling. This realization required us to recalculate sub-bottom depths for the vast majority of the cores from Site 502. We did not "correct" the sub-bottom depths at Site 503. This is especially critical for those cores that do not extend the full 4.4-meter length. Our recalculations involved the following procedure. First, we measured the amount of recovery in each section of a core and subtracted the top portion of Section 1 that was obvious recored material. We identified recored material by its fluidized nature, brecciated texture, and compositional contrast with undisturbed sediment. We could not confidently identify recored material at Site 503. Hence we did not correct Site $\mathbf{5 0 3}$ for recored material. The contact between the recored material and the undisturbed sediment was assigned the depth of the top of the core (Section 1). Second, we found all voids in each section (i.e., zones where the sediment had separated during core handling). The length of these voids was subtracted from the total length of recovery and the sub-bottom depth of the top of the void also assigned to the bottom of the gap. This procedure produces a stratigraphic sequence in each core that is continuous, without voids or recored material. When recovery is not complete, this procedure places the interval of nonrecovery at the bottom of each core. Thus gaps may exist between cores but not within cores. These corrected sub-bottom depths are all annotated on the core forms at the back of each site chapter.

\section{LITHOLOGIC CLASSIFICATION}

The basic lithologic classification used to name sediment type in this volume is a modified version of the system devised by the JOIDES Panel on Sedimentary 
Petrology and Physical Properties. We modified the basic classification to describe only the facies we recovered. Our classification is descriptive, no genetic implication is intended, and the divisions between sediment types are of course artificial. Our assignment of a name was based on properties that were estimated aboard ship.

\section{Descriptive Data}

Names of sediment are defined only on the basis of a qualitative estimate of composition and texture from a microscopic examination of smear slides. Colors were matched with the Geological Society of America GSA Rock-Color Chart, and the full color code is recorded on the core forms at the end of each site chapter.

We used two classes for firmness. Soft is used to denote sediment with little strength that is readily deformed by spatula or finger. The term firm is used to describe sediment that is stiff and resists deformation by spatula or finger. The sediment classification used on Leg 68 is outlined as follows.

\section{Classification and Nomenclature Rules}

1. Rules for class limits and sequential listing of constituents in a sediment name.

A. Major constituents

1. Sediment assumes names of those constituents present in major amounts (major is defined as $>25 \%$ ). See example in Rule $1 \mathrm{~B}$.

2. Where more than one major constituent is present, the one in greatest abundance is listed farthest to the right. The remaining major constitutents are listed progressively farther to the left in order of decreasing abundance. (See example in Rule 1B.)

3. When two or more major constituents are present, class limits are based on percentage intervals: $0-5,5-25,25-75,75-100$ (see the following).

B. Minor constituents

Constituents present in the amounts of 5-25\% are prefixed on the sediment name by the term bearing.

Example: $50 \%$ nannofossils, $30 \%$ radiolarians, $20 \%$ zeolites would be called a zeolite-bearing radiolarian nannofossil ooze. The following examples illustrate Rules $1 \mathrm{~A}$ and $1 \mathrm{~B}$ and the resulting sediment names:

\begin{tabular}{lcl}
\hline $\begin{array}{c}\text { Clay } \\
(\%)\end{array}$ & $\begin{array}{c}\text { Nannofossils } \\
(\%)\end{array}$ & \\
\hline $0-5$ & $95-100$ & $=$ Nannofossil ooze \\
$5-25$ & $75-95$ & $=$ Clay-bearing nannofossil ooze \\
$75-95$ & $5-25$ & $=$ Nannofossil-bearing clay \\
$95-100$ & $0-5$ & $=$ Clay \\
\hline
\end{tabular}

2. Specific rules for calcareous and siliceous tests. A. "Nannofossil" is applied only to the calcareous tests of coccolitholphorids, discoasters, etc.
B. The terms calcareous and siliceous, depending on skeletal composition, are applied where no attempt was made to distinguish fossils as to major subgroup. Thus if no estimate is made, a mixture of radiolarians, diatoms, and silicoflagellates would be called a siliceous ooze. Where this distinction is made, the appropriate fossil name is used.

C. Fossil tests are not qualified by a textural term unless they have been obviously redeposited.

D. The terms ooze, marl, and clay are used to designate $>60 \%, 30-60 \%$, and $<30 \%$ carbonate, respectively.

\section{Determinations of Shipboard Mineralogy and Lithology}

\section{Smear Slides}

Smear slides were the principal means of identification of sediment components onboard the ship. Estimates of component abundances in smear slides are based on a semiquantitative visual estimate using the following classes:

$$
\begin{aligned}
1-5 \% & \text { Rare } \\
5-25 \% & \text { Common } \\
25-75 \% & \text { Abundant } \\
>75 \% & \text { Dominant }
\end{aligned}
$$

Many cores contain important minor lithologies as well as a dominant lithology. The description of the dominant lithology is indicated in most cases, and descriptive information for minor lithologies is included wherever possible. Major and minor abundances from each smear slide examined aboard ship are tabulated in the smear slide summary in each site chapter.

An example of a core form with legend and explanatory notes appears in Figure 2.

\section{BIOSTRATIGRAPHY}

The biostratigraphic framework used for Leg 68 is shown in Figure 3. For the calcareous nannofossils, the Quaternary is subdivided according to zonation of Gartner (1977). The zonations of Martini (1971) and Bukry (1973) are combined to subdivide the Pliocene. The Miocene zonation used follows that of Bukry (1973). The planktonic foraminiferal zonation is that of Jenkins and Orr (1972) developed for the eastern tropical Pacific. Although the zonation of Bolli and Premoli-Silva (1973) is applicable at Site 502, the Jenkins and Orr (1972) zonation is applicable at both Sites 502 and 503 and is used here for comparison between them.

The diatom events are based on the work of Burckle (1977, 1978). This system includes one silicoflagellate event. The radiolarian zonation for the Quaternary is taken from Nigrini (1971). Pliocene and Miocene radiolarian zones are those of Riedel and Sanfilippo (1974).

\section{CORING DEFORMATION}

Four degrees of deformation were recognized and are noted by symbols on the sample core from (Fig. 2). 


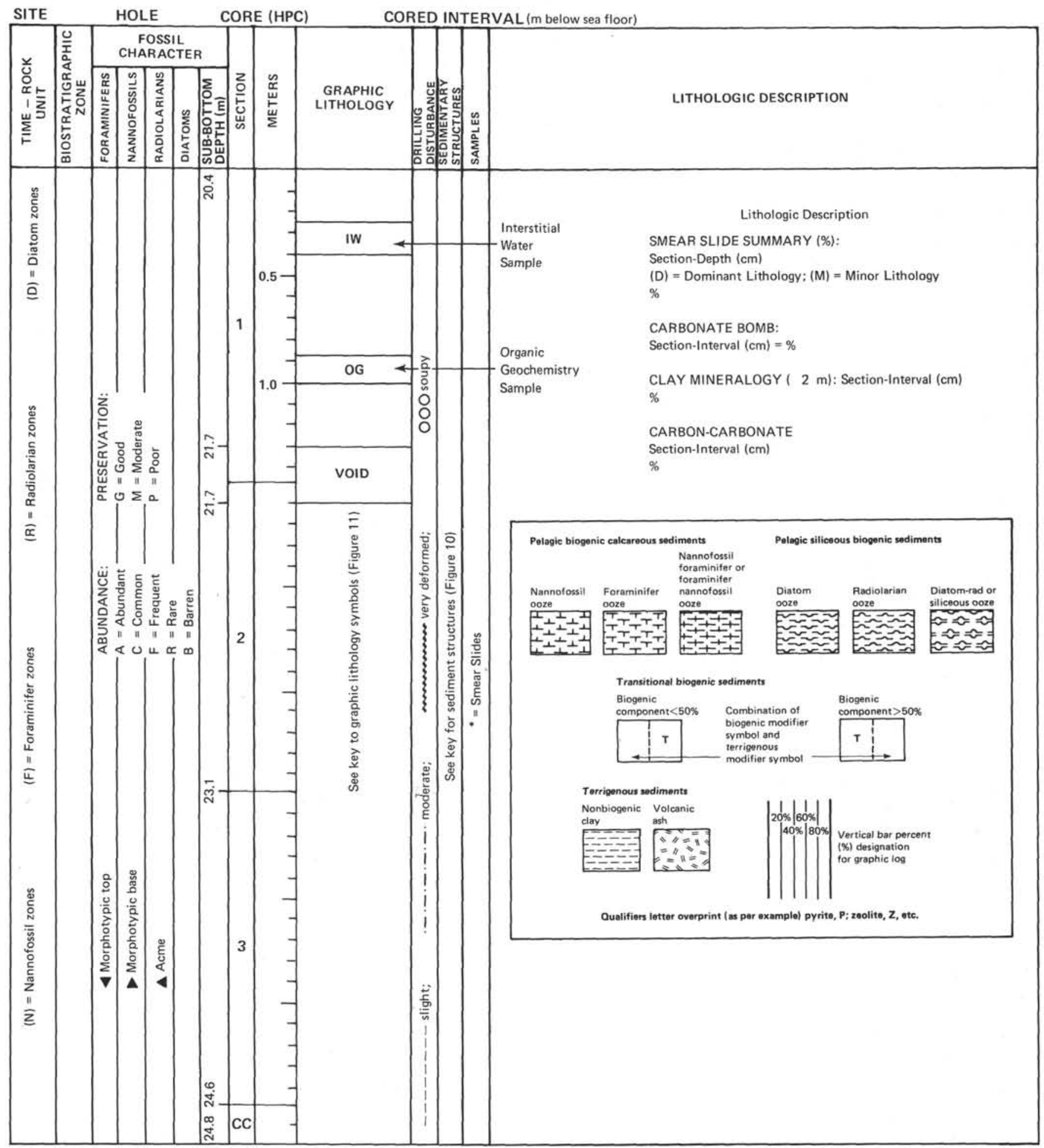

Figure 2. Sample of core form with the various symbols and descriptive codes used in this volume. Note that the graphic lithology column is based solely on the smear slide estimates and does not take into consideration the carbonate bomb data. Also note that the component percentages from smear slides are gross estimates and often do not sum to $100 \%$.

Slightly deformed cores exhibit a slight bending of bedding contacts; extreme bending defines moderate deformation. In highly deformed cores, the original bedding may be completely disrupted so as to produce a "drilling breccia." Watery intervals generally have lost all original bedding characteristics.

\section{CORE FORMS}

The basic lithologic data are contained on core summary forms in both symbolic and descriptive form (Fig. 2). As far as possible the descriptive data are presented in the following order: 


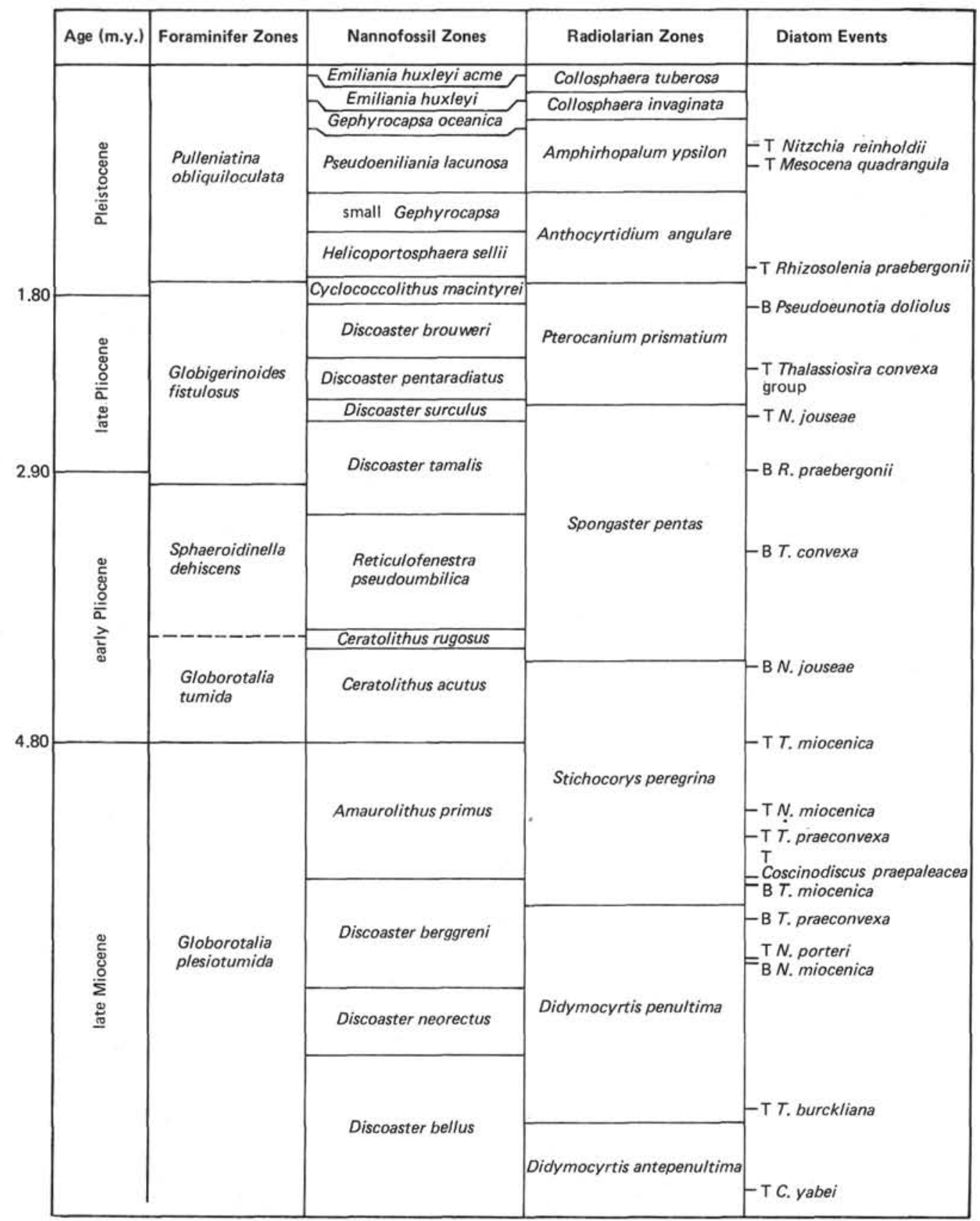

Figure 3. Biostratigraphic framework used as a guide to initially place the Leg 68 samples in a time-stratigraphic sequence. See text of Introduction for the details of this framework.

\section{Sediment name}

\section{Color name and color code number}

The reader is advised that colors recorded in core summaries were determined during shipboard examination immediately after the core sections were split. Experience with carbonate sediment has shown that many of the colors will fade or disappear after opening and storage. Colors particularly susceptible to rapid fading are purple, light and medium tints of blue, light bluish gray, dark greenish black, light tints of green, and pale tints of orange. These colors, change to white or yellowish white or pale tan.
Colors were often cyclic on a scale of $10 \mathrm{~cm}$ or less. This made identification of color boundaries on the core forms virtually impossible. Large-scale color variations are shown and, where possible, small fluctuations in color are indicated. This is especially true for the core forms for Site 503.

\section{Composition}

Composition of the lithologies was determined from examination of smear slides. The lithologic symbols shown on the core form, especially for Site 503, are only average compositions because of the small-scale fluctuations of the lithologic cycles. 


\section{SHIPBOARD ANALYSES}

\section{Physical Properties}

Every effort was made during Leg 68 to sample for physical properties as soon after core retrieval as possible. The primary objective of Leg 68 , however, was to obtain the most detailed stratigraphy possible, and, so as not to compromise this objective, the magnetization of the cores was determined before the physical properties were measured. Nonetheless, in most cases the physical properties measurements were made within three to four hours of the cores' arrival on deck. The physical properties measured on shipboard during Leg 68 (in order that they were made) were

1) Saturated bulk density (by GRAPE);

2) Acoustic velocity (by Hamilton Frame-both through the core liner and on discrete [chunk] samples);

3) Needle penetration-(with AP-210 asphalt needle penetrometer);

4) Shear strength (by miniature vane shear device);

5) a) Water content (by gravimetric techniques);

b) Saturated bulk density (by gravimetric techniques);

c) Porosity (by gravimetric techniques);

d) Grain density (by gravimetric techniques);

6) Salinity of the pore waters.

\section{Saturated Bulk Density by GRAPE}

Unsplit 1.5-meter sections were passed through the Gamma Ray Attenuation Porosity Evaluator (GRAPE). The GRAPE continuously measures the attenuation of a gamma-ray beam as it passes through the core. This attenuation can be directly related to the material mass density, and thereby saturated bulk density, defined here as weight of the sample per unit volume and expressed as grams per cubic centimeter, can be estimated. The principles and use of this device are described in great detail by Evans (1965) and Harms and Choquette (1965); its specific application with DSDP material is described by Boyce (1976).

The GRAPE density values are strongly affected by the degree to which the core material fills the liner and the presence of breaks in the sediment cores. The HPC, however, appears to do an excellent job of completely filling the core liner, thus diminishing this possible source of error. All core sections were run through the GRAPE, and the rare occurrence of breaks in the sediment section was noted so that those points could later be deleted from the saturated bulk density record.

An analog record of downcore GRAPE density variation for each section was produced on shipboard; however, our inability to control the scaling of this display makes the profiles almost useless when density variations are small and gradual, as they are in Leg 68 samples. A digital tape was also made for processing in the shore-based lab. The calibration of the system was checked with aluminum and distilled water standards before each core (three $1.5-\mathrm{m}$ sections) is run. The final processed GRAPE density values were adjusted for these calibration measurements. Despite the continued cali- bration checks, Bennett and Keller (1973) found considerable and unpredictable scatter in the GRAPE density values and warn that these values may be suspect. A comparison by Bennett and Keller (1973) of GRAPE density results and shore-based laboratory data showed that $30 \%$ of the compared values differed by more than $0.05 \mathrm{~g} / \mathrm{cc}$ and that only $36 \%$ agree within $0.02 \mathrm{~g} / \mathrm{cc}$. They also found, however, that the scatter increases with increasing saturated bulk density, indicating that the Leg 68 values, which are all low density, are probably more reliable. Lee (1973) found that on Leg 19, when all samples were considered, GRAPE densities varied from shore-based measurements by about $5 \%$ and by about $2.7 \%$ when those containing gas were eliminated. These errors are probably the result of the lack of complete filling of the core liner by sediment, a consequence of rotary drilling and pumping seawater down the drill pipe and disturbing the sediment. The fact that HPC cores completely fill the liner should eliminate much of this difference, but at this time we will use $2.7 \%$ as an estimate of the accuracy of the Leg 68 GRAPE density values. A comparison of the Leg 68 saturated bulk density values determined by GRAPE with those measured by gravimetric means (see the following) reveals that $48 \%$ of the values agree within $0.02 \mathrm{~g} / \mathrm{cc}$, whereas only $11 \%$ differ by more that $0.05 \mathrm{~g} / \mathrm{cc}$. This is an improvement over the findings of Bennett and Keller (1973), but the true test of the quality of the GRAPE values must await the laboratory determination of saturated bulk density on the carefully selected consolidation and 2 min. GRAPE samples.

Fifty-eight samples (approximately 1 per $4.5 \mathrm{~m}$ of core) were taken at Site 503 for "GRAPE 2-Minute Special" measurements. These samples were taken with $i$ in. high, 1-in. diameter stainless steel cylinders that were carefully pushed into the sediment, dug out, and trimmed. Two Plexiglas plates were then placed on the open ends of the cylinder and the sample placed in the GRAPE for a 2-min. static mode count. The long counting time over a well-controlled path provides an extremely precise measurement. The samples were sealed in wax after the GRAPE analysis, placed under seawater, and kept refrigerated until shore-based measurements could be made.

\section{Acoustic Velocity}

Once the GRAPE measurements were completed the speed of a compressional sound wave through the sediment was measured at at least one point per 1.5 meters of section, and more frequently if lithologic contrasts were obvious. Measurements were made at $400 \mathrm{kHz}$ with a Hamilton Frame velocimeter. This device and the procedures for its use are described in detail in Boyce (1973). Two types of measurements were made at each location. Travel times were determined through the sediment (parallel to bedding) while it was still in a half core liner-that is, one transducer was directly on the sediment while the other was on the core liner. These measurements are referred to as TTL (through the liner). The second mode of measurement involved carefully removing a small chunk of sediment and measuring the 
sound speed through this chunk. Both transducers are in direct contact with the sediment in this mode (referred to as CHUNK). The calibration procedures described by Boyce (1976) were followed and the appropriate correction factors calculated. The accuracy of this system is $\pm 2 \%$ if a single observer makes all the measurements. All velocity measurements were made by a single observer on Leg 68.

\section{Needle Penetration}

At the same time as the velocity measurements were made, an AP-210 needle penetrometer (ASTM, 1973) was used to drop a needle from $1 \mathrm{~cm}$ above the sediment surface and determine its depth of penetration. These measurements were made approximately every $50 \mathrm{~cm}$ down the core in the plane parallel to bedding.

\section{Shear Strength}

Once the sound velocity and penetration measurements were completed, a site was selected for a vane shear measurement of shear strength. The vane shear device measures cohesion in silts and clays. The shear strength measurements reported here are thus measurements of cohesion for those samples that do not have appreciable amounts of sand-sized material. Sections of the core that showed any signs of disturbance were avoided. An obviously disturbed area was sampled occasionally to provide a comparison. These "disturbed" samples will always be identified as such and eliminated from the data synthesis. Shear strength measurements were made approximately once per core $(4.5 \mathrm{~m})$, usually in the middle of the second (middle) section. Measurements were made more frequently around major lithologic contrasts. The temperature of the sediment was measured as the shear vane measurement was being made.

A modified Wykeham Farrance miniature vane shear device was used on Leg 68. The vane itself measured $1.24 \mathrm{~cm}$ (height) $\times 1.27 \mathrm{~cm}$ (diameter) and was inserted with the vane axis perpendicular to the axis of the core (parallel to bedding) until the vane was buried. The vane was rotated through a calibrated spring by a motor at a rate of approximately $89^{\circ}$ per minute. The sediment was remolded by rapidly rotating the vane approximately $720^{\circ}$ in the same direction after a peak torque value was obtained. A second measurement was then made to determine remolded shear strength. A thorough discussion of the DSDP miniature vane shear apparatus can be found in Boyce (1977).

\section{Gravimetric Techniques}

Once velocity measurements were completed on the "chunk" sample, the material was sealed in a plastic vial and refrigerated. Some time later (usually several hours), these samples were used for gravimetric analyses. These analyses include the following.

\section{Water Content}

Water content values reported are "wet water contents" defined as water content = weight of seawater/ weight of wet sediment and expressed as a percentage. The wet "chunk" sample was weighed on a Ohaus cen- togram balance. The sample was then dried for 24 hours at $110^{\circ} \mathrm{C}$ and allowed to cool in a dessicator for at least $2 \mathrm{hr}$. before it was weighed. The values reported have not been corrected for salt content. The accuracy of the weighing is $\pm 1 \%$ and results in an absolute precision of $\pm 2 \%$ for the wet water content measurements.

\section{Saturated Bulk Density}

Bulk density values are "'saturated bulk densities," defined as saturated bulk density $=$ weight of wet sediment/volume of wet sediment and expressed as g/cc. The sample volume was determined by weighing the chunk while it was immersed in water. The precision of this measurement is $\pm 0.01 \mathrm{~g} / \mathrm{cc}$. No salt correction is required for the density calculation.

\section{Porosity}

Porosity is defined as porosity = volume of pore space/volume of wet sediment expressed as a percentage. The volume of the pore space was calculated by dividing the difference between the wet and dry weight of the sediment by the density of the pore fluid. Data reported here have not been corrected for salt content. Precision of the measurement is $\pm 3 \%$.

\section{Grain Density}

Grain density is defined as grain density = weight of solid minerals/volume of solid minerals expressed as $\mathrm{g} / \mathrm{cc}$. Grain density was calculated using the previously defined measurements of porosity and saturated bulk density. This method is not precise, especially at high porosities, and values should be considered rough approximations.

\section{CALCIUM CARBONATE DETERMINATIONS}

Aboard ship, calcium carbonate content was measured by the carbonate bomb technique (Müller and Gastner, 1971). These values are reported on the core forms.

\section{PALEOMAGNETICS}

Each 1.5-meter-long section was spun in the long-core spinner magnetometer and readings were taken every 10 $\mathrm{cm}$ down the length. The noise level and response characteristics of the long-core spinner magnetometer are discussed in Kent and Spariosu (this volume). Discrete samples were taken periodically and measured with a traditional sample magnetometer. Ages were assigned using the revised geomagnetic polarity time scale of LaBrecque et al. (1977) with corrected ages after Mankinen and Dalrymple (1979).

\section{REFERENCES}

American Society for Testing and Materials, 1973. Standard method of test for penetration of bituminuous materials. Ann. Book ASTM Stand., Pt. 11(D-5):10-13.

Bennett, R. H., and Keller, G. H., 1973. Physical properties evaluations. In Van Andel, Tj. H., Heath, G. R., et al., Init. Repts. DSDP, 16: Washington (U.S. Govt. Printing Office), 521-528.

Bolli, H. M., and Premoli-Silva, I., 1973. Oligocene to Recent planktonic foraminifera and stratigraphy of the Leg 15 sites in the Caribbean Sea. In Edgar, N. T., Saunders, J. B., et al., Init. Repts. DSDP, 15: Washington (U.S. Govt. Printing Office), 475-498. 
Boyce, R. E., 1973. Appendix I. Physical property methods. In Edgar, N. T., Saunders, J. B., et al., Init. Repts. DSDP, 15: Washington (U.S. Govt. Printing Office), 1115-1128.

1976. Definitions and laboratory techniques of compressional sound velocity parameters and wet-water content, wet-bulk density, and porosity parameters by gravimetric and gamma-ray attenuation techniques. In Schlanger, S. O., Jackson, E. D., et al., Init. Repts. DSDP, 33: Washington (U.S. Govt. Printing Office), 931-958.

1977. Deep-Sea Drilling Project procedures for shear strength measurement of clayey sediment using modified Wykeham Farrance and laboratory vane apparatus. In Baker, P. F. Dalziel, I. W. D., et al., Init. Repts. DSDP, 36: Washington (U.S. Govt. Printing Office), 1059-1068.

Bukry, D., 1973. Low-latitude coccolith biostratigraphic zonation. In Edgar, N. T., Saunders, J. B., et al., Init. Repts. DSDP, 15: Washington (U.S. Govt. Printing Office), 685-703.

Burckle, L. H., 1977. Pliocene and Pleistocene diatom datum levels from the equatorial Pacific. Quat. Res., 7:330-340.

1978. Early Miocene to Pliocene diatom datum levels for the equatorial Pacific. Geological Research and Development Center, Republic of Indonesia, Special Publ., 1:25-44.

Curray, J. R., Moore, D. G., et al., 1979. Leg 64 seeks evidence on development of basins. Geotimes, 24:18-20.

Edgar, N. T., Saunders, J. B., et al., 1973. Init. Repts. DSDP, 15: Washington (U.S. Govt. Printing Office).

Evans, H. B., 1965. GRAPE-A device for continuous determination of material density and porosity. Trans. SPWIA Logging Symposium, 6th Ann. Dallas, Texas, 2:B1-B25.

Gartner, S., 1977. Calcareous nannofossil biostratigraphy and revised zonation of the Pleistocene. Mar. Micropaleont., 2:1-25.

Harms, J. C., and Choquette, P. W., 1965. Geologic evaluation of a gamma-ray porosity device. Trans. SPWLA. Logging Symposium, 6th Ann., Dallas, Texas, 7:C1-C37.
Hays, J. D., et al., 1972. Init. Repts. DSDP, 9: Washington (U.S. Govt. Printing Office).

Jenkins, D. G., and Orr, W. N., 1972. Planktonic foraminiferal biostratigraphy of the eastern equatorial Pacific, DSDP Leg 9. In Hays, J. D., et al., Init. Repts. DSDP, 9: Washington (U.S. Govt. Printing Office), 1059-1193.

LaBrecque, J. L., Kent, D. V., and Cande, S. C., 1977. Revised magnetic polarity time scale for Late Cretaceous and Cenozoic time. Geology, 5:330-335.

Lee, H. J., 1973. Measurements and estimates of engineering and other physical properties Leg 19. In Creager, J. S., Scholl, D. W. et al., Init. Repts. DSDP, 19: Washington (U.S. Govt. Printing Office), 701-720.

Mankinen, E. A., and Dalrymple, G. B., 1979. Revised geomagnetic time scale for interval 0-5 m.y.B.P. J. Geophy. Res., 84:615-626.

Martini, E., 1971. Standard Tertiary and Quaternary calcareous nanno-plankton zonation. In Garinacci, A. (Ed.), Proceeding of the II Planktonic Conference, Roma 1970: Rome (Edizioni Tecnoscienza), 2:739-777.

Müller, G., and Gastner, M., 1971. The "Karbonat Bombe," a simple device for the determination of carbonate content in sediments, soils, and other materials. Neues Jahrb. Mineral. Monatsh., 10: 466-469.

Nigrini, C. A., 1971. Radiolarian zones in the Quaternary of the equatorial Pacific Ocean. In Funnell, B. M., and Riedel, W. R., (Eds.), The Micopaleontology of the Oceans: Cambridge, England (Cambridge University Press), pp. 443-461.

Riedel, W. R., and Sanifilippo, A., 1978. Stratigraphy and evolution of tropical Cenozoic radiolarians. Micropaleontology, 24(No. 1):61-96.

Schrader, H. J., Kelts, K., Curray, J., et al., 1980. Laminated diatomaceous sediment from the Guaymas Basin slope (central Gulf of California): 250,000-year climate record. Science, 207:1207-1209. 